\title{
SUBSURFACE STRUCTURE IDENTIFICATION IN ILOTIDEA USING ELECTRICAL METHOD FOR DEVELOPED THE FLOOD TOURIST SCIENCE VILLAGE
}

\author{
Dewi Darmayanti Tolodo ${ }^{1}$, Muhamad Danial Suma ${ }^{1}$, Nana Juhriana Yusuf ${ }^{1}$, Intan Noviantari \\ Manyoe $^{1}$
}

${ }^{1}$ Geological Engineering Major, Science, and Technology Department, Faculty of Mathematics and Science, Gorontalo State University

Email Korespondensi: dewidarmayantitolodo@gmail.com

DOI: 10.31314 /jsig.v2i1.252

Abstract - Gorontalo is one area that is very vulnerable to flooding. Flood problems in Gorontalo must have a solution that can have a positive impact on the community and the government. The purpose of this research is to identification subsurface structure of the Ilotidea Region by using resistivity method. The result of this research will be used for the fundamental of developing the Flood Tourist Science Village. The method that used in this research is to take subsurface data by using the IPMGEO-4200 Electrical Resistivity Meter in 6 points at Ilotidea Village. Processing data through calculating the apparent resistivity ( $\rho a)$ by entering the values $\Delta V, I, R$ and $K$, then interpreting the subsurface structure of the Ilotidea region. Based on the results of the data analysis, there are obtained 5 layers at each data retrieval point. The layers found at each point are composed of sandy clay, clay, sand, clay, and sandstone. Based on the results of the interpretation of the subsurface structure, the sandy clay layer is arranged with a layer of clay which has the characteristic of not easily escaping the water. This causes the Ilotidea area to be very vulnerable to flooding because when surface runoff and rainfall falls into this area has a high intensity and volume it will cause inundation due to the absence of water absorbed by material found below the surface. Based on the subsurface structure of the Ilotidea region, the house foundation that will be made in a flood tourism science village must reach a depth of 5-10 $\mathrm{m}$ where at this depth the layer is a clay layer which is not easy to escape and elastic so the house is not easy to collapse

Keywords: Lithology, Subsurface, Electrical, Flood Tourism, Ilotidea.

\section{INTRODUCTION}

Gorontalo Province has a high flood intensity and almost every year. Flood-prone areas in Gorontalo Province are located in the Gorontalo Regency. Ilotidea Village at Tilango Subdistrict is one of the areas in Gorontalo Regency that is prone to flooding. In 2017 the flood level in the Tilango Subdistrict reaches 7 meters (BNPB, 2017).

Various efforts have been made by the government to tackle flooding that occurred in the Ilotidea area of Tilango Subdistrict, but still, this area is often flooded during the rainy season. Government efforts in tackling floods include making leeve but this solution has a real impact for people in Ilotidea because flooding still occurs when the rainy season arrives.

Research studies that were held on flood-prone areas in Gorontalo (BNPB, 2015) only held mapping flooded areas, but have not provided effective information and solutions for peoples around the area and the government. One solution offered by BNPB (2015) is not to build houses in flood-prone areas. The problem faced by the government today is the tendency of people who continue to build houses in flood-prone areas because the area is the place of birth and livelihood. Based on field observations by researchers in 2017, during a flood, some of Ilotidea's people did not take refuge on the grounds that theft often occurred in abandoned houses.

Flood problems in Gorontalo must have a solution that can have a positive impact on the people and the government. According to the World Meteorological Organization (2009) for the handling of floods needs to pay attention to the conditions of space and time so that more detailed and accurate research needs to be done to obtain effective and beneficial solutions for the people 
and the government. Research on space can be done using electrical methods to determine the structure of the subsurface.

The purpose of this study was to identify the subsurface structure of the Ilotidea area using the electrical resistivity method. The results of this study can be a reference for the development of tourist villages during floods.

\section{METHOD AND DATA}

Electrical research was conducted in March 2019 in 6 points at Ilotidea Village, Tilango Subdistrict, Gorontalo Regency. The first points was in N 00³3'45,69" / E 12301'29,45", second

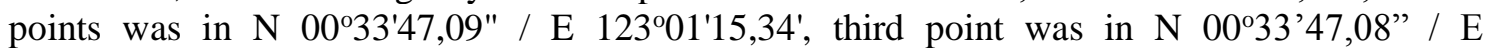

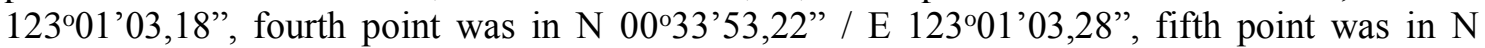
$00^{\circ} 33^{\prime} 52,47^{\prime \prime} / \mathrm{E} 123^{\circ} 01^{\prime} 24,98^{\prime \prime}$, and the sixth point was in N $00^{\circ} 33^{\prime} 53,22^{\prime \prime}$ / E $123^{\circ} 01^{\prime} 03,28^{\prime \prime}$. Location of this research is in Ilotidea Village that geographically borders on Limboto Lake to the west, bordering Lauwonu Village to the north, and Tabumela Village to the south.

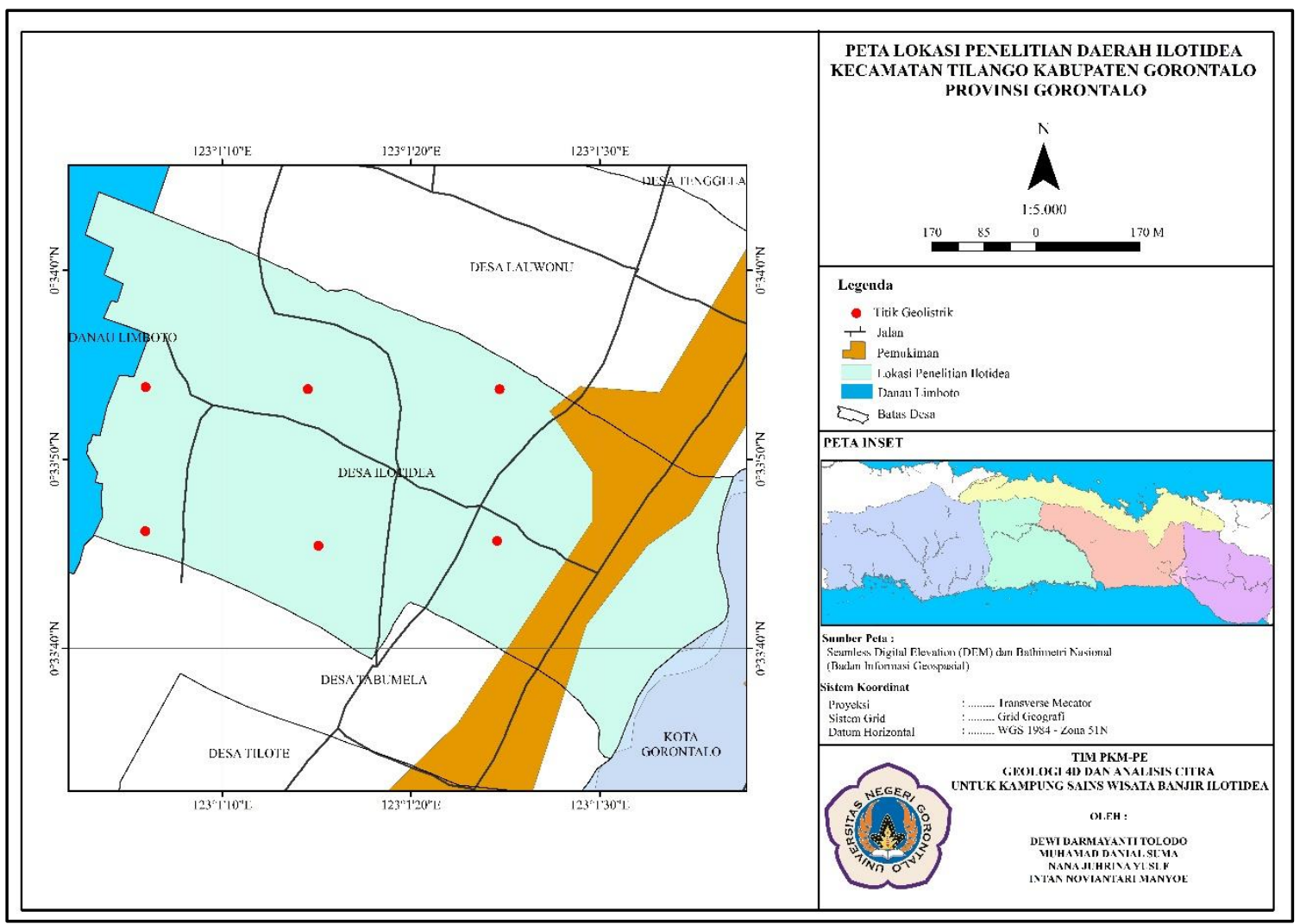

Figure 1. Research location area

Electrical resistivity is one of geophysics methods that studies about the resistivity value of lithology layers in the earth subsurface (Hendrajaya and Idam, 1990). In this method, an electric current is injected into the earth through two current electrodes and a potential difference measurement is carried out through two potential electrodes. From the results of measurements of current and electric potential, variations of resistivity value can be calculated (Apparao, 1997). The measurement of the electrical resistivity method is using the resistivity sounding. Resistivity sounding is intended to determine the distribution of vertical lithology layers. The electrode arrangement of the resistivity sounding method uses the Schlumberger configuration. Resistivity data retrieval uses 1 Set of IPMGEO-4200 Electrical Resistivity Meter, GPS Garmin, and Brunton Compass.

The first step in data processing is by calculating the apparent resistivity ( $\rho$ a) by entering the values of $\Delta \mathrm{V}, \mathrm{I}, \mathrm{R}$ and $\mathrm{K}$. 
The $\mathrm{K}$ value is obtained by the formula:

$$
K=\frac{\pi\left(L^{2}-l^{2}\right)}{2 l}
$$

Apparent resistivity ( $\rho$ a) value is obtained by the formula:

$$
\rho a=K \frac{V}{I}
$$

Furthermore, rock layer interpretation and modeling are carried out by considering the surface geological conditions of the study area.

\section{RESULT AND DISCUSSION}

Electricity data collection was carried out at 6 points scattered in Ilotidea Village. After data retrieval, the layers are interpreted at each point. Based on the results of processing data obtained results as follows below :

Table 1. Table of data processing in point 1

\begin{tabular}{cccc}
\hline $\mathrm{N}$ & $\mathrm{P}$ & $\mathrm{h}$ & $\mathrm{d}$ \\
\hline 1 & 0,23 & 2,23 & 2,23 \\
2 & 50,1 & 3,57 & 5,8 \\
3 & 120 & 14,2 & 20 \\
4 & 85,2 & 10,4 & 30,4 \\
5 & 467 & & \\
\hline
\end{tabular}

* N: layer, $\rho$ : resistivity value, h: layer thick, dan d: layer depth

Table 2. Table of data processing in point 2

\begin{tabular}{cccc}
\hline $\mathrm{N}$ & $\mathrm{P}$ & $\mathrm{h}$ & $\mathrm{d}$ \\
\hline 1 & 12,5 & 3,98 & 3,98 \\
2 & 59,4 & 10 & 14 \\
3 & 75,6 & 11,7 & 25,7 \\
4 & 101 & 6,2 & 31,9 \\
5 & 410 & & \\
\hline
\end{tabular}

* N: layer, $\rho$ : resistivity value, h: layer thick, dan d: layer depth

Table 3. Table of data processing in point 3

\begin{tabular}{cccc}
\hline $\mathrm{N}$ & $\rho$ & $\mathrm{h}$ & $\mathrm{d}$ \\
\hline 1 & 9,61 & 2,23 & 2,23 \\
2 & 34,6 & 3,57 & 5,8 \\
3 & 117 & 14,2 & 20 \\
4 & 85 & 10,4 & 30,4 \\
5 & 319 & & \\
\hline
\end{tabular}

* N: layer, $\rho$ : resistivity value, h: layer thick, dan d: layer depth

Table 4. Table of data processing in point 4

\begin{tabular}{cccc}
\hline $\mathrm{N}$ & $\mathrm{P}$ & $\mathrm{h}$ & $\mathrm{d}$ \\
\hline 1 & 11,2 & 5,78 & 5,78 \\
2 & 59,4 & 9,42 & 15,2 \\
3 & 80 & 8,05 & 23,3 \\
4 & 112 & 8,06 & 31,3 \\
5 & 421 & & \\
\hline
\end{tabular}

* N: layer, $\rho$ : resistivity value, h: layer thick, dan d: layer depth 
Table 5. Table of data processing in point 5

\begin{tabular}{cccc}
\hline N & P & h & d \\
\hline 1 & 10,4 & 4 & 4 \\
2 & 72,6 & 5 & 9 \\
3 & 120 & 5 & 14 \\
4 & 85,2 & 16 & 30 \\
5 & 467 & & \\
\hline
\end{tabular}

* N: layer, $\rho$ : resistivity value, h: layer thick, dan d: layer depth

Table 6. Table of data processing in point 6

\begin{tabular}{cccc}
\hline $\mathrm{N}$ & $\rho$ & $\mathrm{h}$ & $\mathrm{d}$ \\
\hline 1 & 13,4 & 8,27 & 8,27 \\
2 & 80,2 & 7,58 & 15,9 \\
3 & 90,2 & 5 & 20,9 \\
4 & 120 & 10,4 & 31,3 \\
5 & 443 & & \\
\hline
\end{tabular}

* N: layer, $\rho$ : resistivity value, h: layer thick, dan d: layer depth

Based on the results of data processing, it is obtained that at point 1 the first layer is the sandy clay material layer with thickness $2.3 \mathrm{~m}$. The second layer is located at a depth of 2.3-5.8 $\mathrm{m}$ which is a clay material layer. The third layer is sand material that located at depth $5.8-20 \mathrm{~m}$. The fourth layer is clay material layer which is located at depth of $20-30.4 \mathrm{~m}$. The fifth layer is located at depth $>30.4 \mathrm{~m}$ is sandstone layer.

In point 2 area, the first layer is found in the depth 0-3.98 $\mathrm{m}$ is a layer of sandy clay material. The second layer is located at a depth of 3,98-14 $\mathrm{m}$ is clay material layer. The third layer is a layer of sand material located at a depth of 14-25.7 m. The fourth layer is a layer of clay material which is located at depth of 25.7-31.9 m. At depth $>31.9 \mathrm{~m}$ is a layer of sandstone.

Table 7. Resistivity Value based on Varhoef (1989) and Telford (1990).

\begin{tabular}{cc}
\hline Material & Resistivity Value \\
\hline Clay & $8-100 \Omega \mathrm{m}$ \\
Sandy Clay & $40-250 \Omega \mathrm{m}$ \\
Sand & $100-60 \Omega \mathrm{m}$ \\
Sandstone & $50-500 \Omega \mathrm{m}$ \\
\hline
\end{tabular}

In point 3 areas, the first layer is a layer of sandy clay material located at a depth of $0-2.3$ $\mathrm{m}$. The second layer is sand material layer located at depths 2.3 to $5.8 \mathrm{~m}$. The third layer is clay material layer located at a depth of 5.8-20 m. The fourth layer is clay layer that located at depth 20-30.4 m. The fifth layer is sandstones layer located at the depth of $>30.4 \mathrm{~m}$.

In point 4 area, the first layers found in this area is a layer of sandy clay located at a depth of $0-5,78 \mathrm{~m}$. The second layer is clay material layer located at depth of 5.8 to $15.2 \mathrm{~m}$. The third layer is sand layer that is located at depth of 15.2 to $23.3 \mathrm{~m}$. The fourth layer is clay material which is located at a depth 23.3-31.3 m. The last layer is sandstone layer that laying at depth $>31,3 \mathrm{~m}$.

In point 5 areas, the first layer is sandy clay which is located at a depth of $0-4 \mathrm{~m}$. In the second layer is clay material that located at a depth of 4-9 $\mathrm{m}$. The third layer is sand material located at depth of 9-14 m. The fourth layer is clay material located at a depth of $14-30 \mathrm{~m}$. In the fifth layer is a layer of sandstone, this layer is located at a depth of $>30 \mathrm{~m}$.

At point 6 area, layers that found in this area consists of a layer of sandy clay, clay material layer, sand material layer, clay material layer, and sand layer. The sandy clay layer that located at depth of 0-8.27 m. Clay material layers are located at a depth of 8.27 to $15.9 \mathrm{~m}$. Sand material layer is found at $15.9-20.9 \mathrm{~m}$. Clay layer is located at depth of $20.9-31.3 \mathrm{~m}$. The last layer is sandstone layer that located at $>31.3 \mathrm{~m}$. 


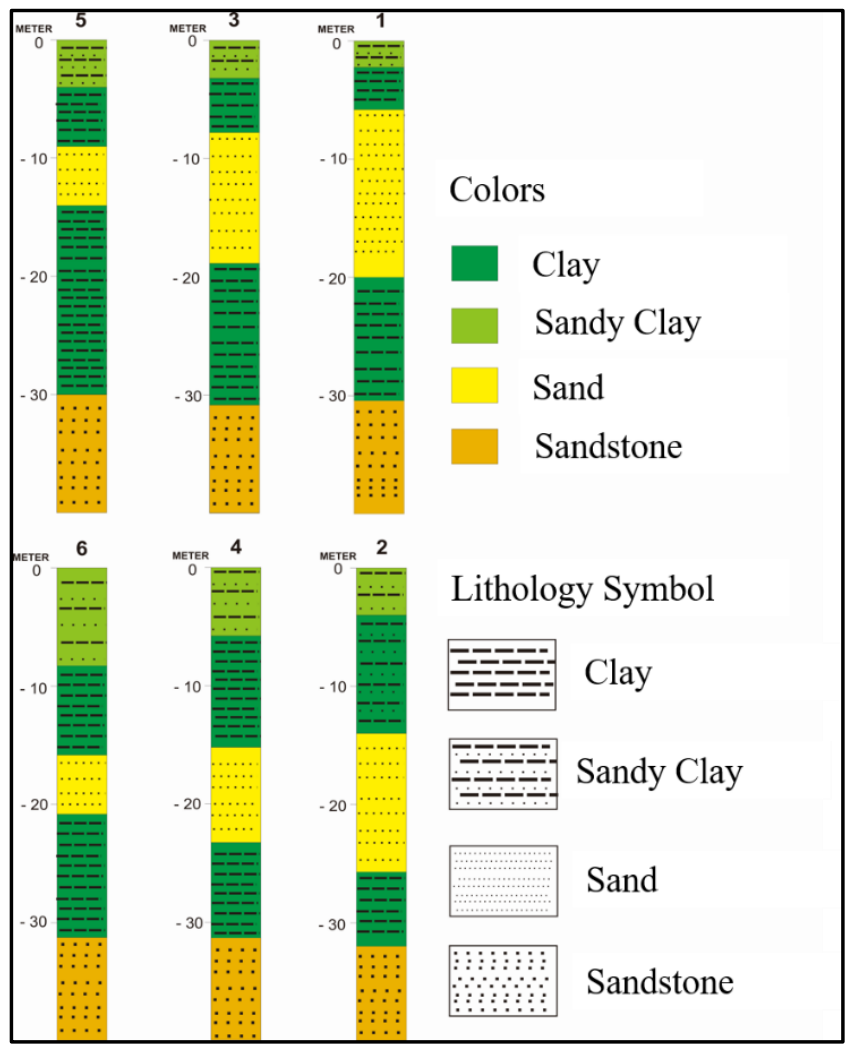

Figure 2. Interpretation of subsurface structure

Based on the results of the analysis data, there is 5 layers lying in Ilotidea. Layer that interpretation lying in Ilotidea consist of sandy clay layer, clay material, sand material, clay material, and sandstone material layers. Based on the Wentworth scale, clay material has finegrained characteristics with grain size $<0.004 \mathrm{~mm}$ and is not easy to escape the water. Sand material has a coarse-grained character and has good porosity, which is easy to escape the water.

Based on the results of the layer interpretation in picture 2, the sandy clay and clay material are lying nearest surface that's causing the surface runoff around the Ilotidea area will not convenient to precipitated by the soil. This case causes the Ilotidea area highly vulnerable to flooding if rainfall falls into this area has a high intensity and volume.

Development of a flood tourism village can be viewed from various aspects, one of that aspect is the science aspect such as the structure of the earth's layer. Reviewing this aspect is very important as a consideration for the design and security of the house that will become a tourist village. Based on the subsurface structure of the Ilotidea region, the foundation of the house that will be built for tourism must reach into depth of 5-10 $\mathrm{m}$ where at this depth the layers in this area are clay layers which are not easy to escape the water and has elastic characters so the house is not broke easily. In addition, the foundation at the surface must be made high, so that house can safe from flooding.

\section{CONCLUSION}

The structure of the subsurface found in the Ilotidea region is composed of layers of sandy clay material, clay material layers, sand material layers, clay material layers, and sandstone layers. Based on the results of these interpretations, it can be concluded that in order to develop a flood tourism science village, the house to be built must have a foundation at a depth of 5-10 m or must reach the clay layer.

\section{ACKNOWLEDGMENT}

We would like to thank the Ministry of Research and Technology of Higher Education (RISTEK DIKTI) for contributing to this research so that, this research can be carried out well and smoothly. 


\section{REFERENCE}

Apparao and Ankaraboyina, 1997. Developments In Geoelectrical Methods. Balkema, Rotterdam.

Hendrajaya L. and Idam A., 1990. Monograf, Geolistrik Tahanan Jenis. Laboratorium Fisika Bumi ITB. Bandung.

Badan Nasional Penanggulangan Bencana, 2015. Kajian Resiko Bencana Gorontalo 2016-2020. Deputi Bidang Pencegahan dan Kesiapsigaan Badan Nasional Penanggulangan Bencana. Gorontalo.

Badan Nasional Penanggulangan Bencana, 2017. Data Kejadian Bencana di Indonesia. Publikasi Badan Nasional Penanggulangan Bencana. http://dibi.bnpb.go.id/. 20 April 2019 (14:53).

Reynold J.M., 1997. An Introduction to Applied and Environmental Geophysics. John Wiley and Sons Ltd., New York.

Telford, W.M., Geldart, L.P., Sheriff, R.E. and Keys, D.A. 1990. Applied Geophysics, 2nd Edition. Cambridge University Press, Cambridge: London, New York, Melbourne.

Verhof, P.N.W., 1994. Geologi Untuk Teknik Sipil. PT. Erlangga. Jakarta. Indonesia

World Metorological Organization, 2009. Integrated Flood Management Concept Paper. Publications Board World Meteorological Organization (WMO). Switzer 